\title{
A Study of Effects of Specialized Marketing Capabilities on Performance Marketing unit Based on Morgan et al Case: A Case of Past Industry in Tehran
}

\author{
Robabe Seifi \\ MA Student, Department of Management, Najaf Abad Branch, Islamic Azad University, Isfahan, \\ Iran

\section{Mohamad Reza Dalvi} \\ Assistant Professor, Dep. of Management, Dehaghan Branch, Islamic Azad University, Isfahan, \\ Iran
}

DOI: $\quad 10.6007 /$ IJAREMS/v3-i1/601

URL: http://dx.doi.org/10.6007/IJAREMS/v3-i1/601

\begin{abstract}
Today, specialized marketing capabilities is a infrastructure of marketing services and critical to many organizations. The aim of this study examines the impact of specialized Marketing capabilities on outcomes and factors performance marketing unit in Tehran city. Total number of all managers of the 10 past industry, is 80 statistically. And includes one independent variables and one dependent variable. In this study, two questionnaires were used to measure variables. Reliability (Cronbach's alpha) for both instruments at the desired level is obtained. The sample survey of 80 managers of past industry in the city. In this regard the model was designed To illustrate the effect of specialized marketing capabilities on outcomes and factors performance marketing unit results were analyzed using spss, Lisrel software. This study included 7 hypotheses is descriptive correlation method is. Based on the results of the analysis of data collected it was found that there is a positive correlation between specialized marketing capabilities and marketing Performance
\end{abstract}

\section{Introduction}

The development of specialized marketing capabilities in order to enhance competitiveness and performance of firms has gained considerable interest in the management literature. The resource based view of the firm places a great emphasis on competing on the basis of capabilities, both specialized marketing capabilities and architectural marketing capabilities. To achieve competitive advantage, businesses must develop capabilities in different functional areas (Prahalad and Hammel, 1990). Capabilities have been defined as complex bundles of skills and collective learning, exercised through organisational processes that ensure coordination of functional activities. (Day 1994, p.38). Therefore, a key task for the firm is to identify those capabilities that will provide a sustainable competitive advantage. To be sustainable, these capabilities must be difficult to imitate and should support the organisation's business strategy (Day and Wensley, 1988; Barney, 1991; Day, 1994). Moreover, these capabilities must be rare, complex and tacit (Johnson and Scholes 1999). Capabilities 
should be rare because competitors must find them difficult to emulate; they are complex because they are explained by a number of linked factors as in the creation of superior customer value, and they are tacit because they are inextricably embedded in organisational experience and practise. (Johnson \& Scholes, 1999)

\section{Literature Review And Hypotheses}

Our study allow us to make three contributions to the literature. First, drawing on the implementation literature in marketing and management, we offer a new conceptualization and operationalization of marketing capabilities effectiveness centered on two aspects that are key to understanding its relationship with performance marketing unit : (1) Specialized marketing capabilities, encompass the tactical marketing program-related processes commonly needed to implement marketing strategy (Bonoma 1985; Vorhies and Morgan 2003)., and (2) Architectural marketing capabilities encompass the information related processes involved in learning about the export venture market and the planning-related processes involved in selecting export marketing strategy goals and formulating strategies to attain them (Morgan et al. 2003; Slotegraaf and Dickson .Second, using primary survey data from a large sample in manufacturing companies, we empirically link marketing capabilities with performance marketing unit outcomes. Our model not only provides empirical support for the proposed linkages but also explains substantial variance in performance marketing unit. Thus, our study provides compelling evidence that the marketing capabilities is an important component of firms competitiveness. Third, we identify and examine the important role of marketing capabilities in enabling firms to successfully performance marketing unit Importantly, our findings suggest that most of the performance marketing unit benefits of marketing capabilities are realized through the effective implementation of planned specialized marketing capabilities. This offers new theoretical insights into how and why marketing capabilities are important sources of competitive advantage and performance marketing unit We begin by describing the theoretical framework for our study, outlining in detail our conceptualization of marketing capabilities and linking this with performance marketing unit. Next, we develop our research hypotheses. We then describe the research method used to test the hypothesized relationships and present the results. Finally, we discuss the findings and their implications, consider limitations of our study, and identify important areas for future research. Theory framework The marketing literature suggests that the effective marketing capabilities is a key driver of firm

\subsection{Marketing Capabilities}

An important aspect of this research is understanding what role marketing capabilities play in attaining and maintaining competitive advantage. To do this, it is necessary to understand how these capabilities develop within the export performance. Marketing capabilities can be defined as integrative processes designed to apply the collective knowledge, skills, and resources of the firm to the market-related needs of the business, enabling the business to add value to its goods and services and meet competitive demands (Day 1994). this study investigates six marketing areas for evidence of capabilities. That including : marketing research, pricing , product development., distribution., Promotion, marketing management 
capabilities It is also important to note that each marketing capability area is conceptualised as existing relative to competitors (Grant 1991).

\subsection{Two types of Marketing capabilities}

First are architectural marketing capabilities, the processes by which the exporting firm learns about its export venture market and uses this insight to make appropriate export marketing strategy decisions (e.g., Morgan et al. 2003; Teece et al. 1997). architectural marketing capabilities activities including the routines used to gather, process, and interpret export market information; distribute relevant foreign market information to export decision makers; and develop export venture marketing strategies (Day 1994; Vorhies and Morgan 2005). Second are specialized marketing capabilities, the "blocking and tackling" export marketing program-related processes needed to implement export marketing strategies (Grant 1996; Vorhies et al. 2009). specific marketing capabilities, activities including export product and pricing management, distribution management and delivery, post-sales service, marketing communications, and selling processes that a firm may need to transform its available resources into planned value offerings for target customers in the export venture market(Day 1994; Vorhies and Morgan 2003).

\subsection{Research hypotheses:}

The conceptual model for the current study, based on the above-mentioned discussions on the literature, is presented in figure 1. According to the model, effective factors on performance marketing is separated in two main categories: i. Independent variable: specialized marketing capabilities Dependent variable: performance marketing The current studies aims at investigating the effective factors on performance marketing, the main question of the study is "What variables are effective on performance marketing " So the hypotheses of the study, with the aim to answer this main question, and with regard to the proposed model, are as follow:

Figure 1 .the conceptual framework of study 


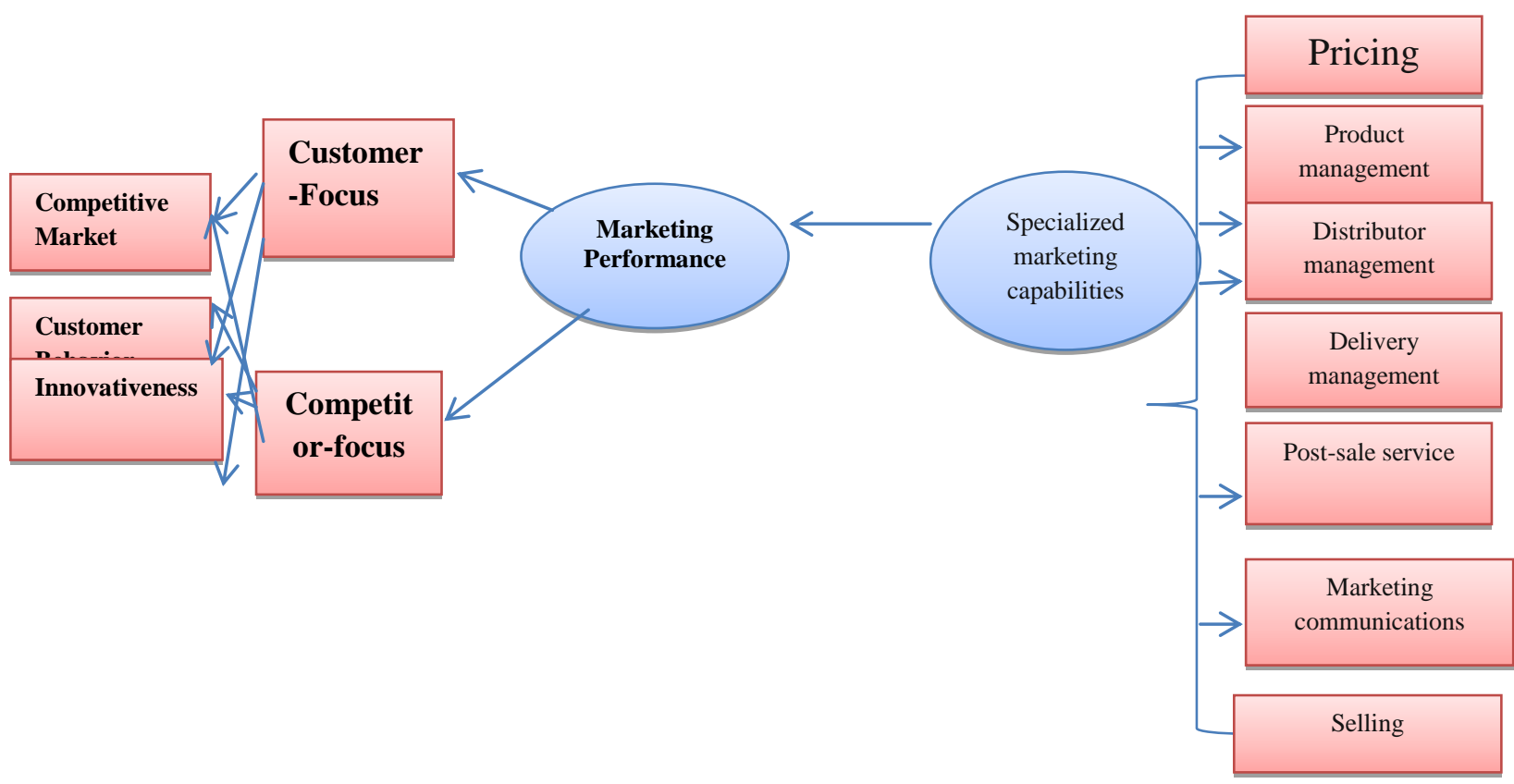

\section{Hypotheses}

For studying the a study effects specialized marketing capabilities on performance marketing unit, we test the following hypotheses

Ha: Specialized marketing capabilities are positively related performance marketing

Ha1: Pricing is positively related performance marketing

Ha2: Product management is positively related performance marketing

Ha3: Distributor management is positively related performance marketing

Ha4: Delivery management is positively related performance marketing

Ha5: Post-sale service is positively related performance marketing

Ha6 :Marketing communications is positively related performance marketing Ha7: Selling is positively related performance marketing

\section{Research Method}

\subsection{Research Goal}

In this survey we aim to identify the study effects specialized marketing capabilities on performance marketing unit To test the propositions, a field survey using questionnaires was conducted.

\subsection{Measures}


The constructs in our study are developed by using measurement scales adopted from prior studies. All constructs are measured using five-point Likert scales ranging from 1=strongly disagree to 5=strongly agree. Items for measuring specialized marketing capabilities are adopted This scale consists of seven dimensions, Pricing, Product management , Distributor management , Delivery management, Post-sale service, Marketing communications, Selling .To measure a fir specialized marketing capabilities, its position relationship to performance marketing.

\subsection{Sample and Data Collection}

The hypothesized relationships will be tested with data collected through structured questionnaires administered face-to-face to marketing unit employees of firms located in Tehran . Data were collected through face-to-face interviews with marketing unit employees of the : Past industry in Tehran. Sample size of the study is 80.

\subsection{Validity and reliability}

Construct validity of the questionnaire was measured utilizing exploratory and confirmatory factor analyses. For measuring reliability, the Cronbach's alpha factor was calculated for all the variables which resulted in following values: 0.78 for specialized marketing capabilities, 0.80 performance marketing unit all in the acceptable range

\begin{tabular}{|c|c|c|}
\hline Variables & $\begin{array}{l}\text { Number } \\
\text { question }\end{array}$ & a-Chronbach \\
\hline $\begin{array}{l}\text { Specialized Marketing } \\
\text { Capabilities }\end{array}$ & $1-23$ & $0 / 78$ \\
\hline Performance marketing & $24-42$ & $0 / 80$ \\
\hline
\end{tabular}

\subsection{Population and sample}

Research population includes managers in 9 Past industry winter 2012.A total of 100 usable replies were obtained, However, 80 is completed questionnaire. Having distributed 100 questionnaires among sample members, descriptive data analysis is exhibited in table 2 . as shown in table 2, from 80 respondents,, 39/5 percent were Tenants and 62/2 percent were married. The respondents' age average was 36 to 50, and more than 50/1 percent of them had a Bachelor degree.

\section{Table-2}




\section{Descriptive data analysis}

\begin{tabular}{|c|c|c|c|c|c|}
\hline Gender & $\%$ & Age & & Education & $\%$ \\
\hline $\begin{array}{l}\text { Home } \\
\text { owener }\end{array}$ & $63 / 9$ & 18 to 22 & $30 / 5$ & $\begin{array}{l}\text { Under } \\
\text { Diploma }\end{array}$ & $14 / 9$ \\
\hline Tenants & $39 / 5$ & 23 to 35 & $20 / 8$ & Diploma & $15 / 9$ \\
\hline $\begin{array}{l}\text { Marital } \\
\text { Status }\end{array}$ & $0 / 00$ & 36 to 50 & $42 / 7$ & Bachelor & $50 / 1$ \\
\hline Married & $62 / 2$ & $\begin{array}{l}50 \text { and } \\
\text { over }\end{array}$ & $7 / 1$ & $\mathrm{MA}$ & $13 / 5$ \\
\hline Single & $32 / 9$ & & & Master & 0 \\
\hline
\end{tabular}

\section{Experimental model}

The data collected was analyzed using LISREL which is a multivariate modeling technique. LISREL aims to explain the structure or pattern among a set of latent (unobserved or theoretical) variables, each measured by one or more manifest (observed or empirical) and typically fallible indicators. The LISREL model assumes a causal structure among a set of latent variables. These latent variables appear as underlying causes of the observed variables

Figure 2. Conceptual framework of study

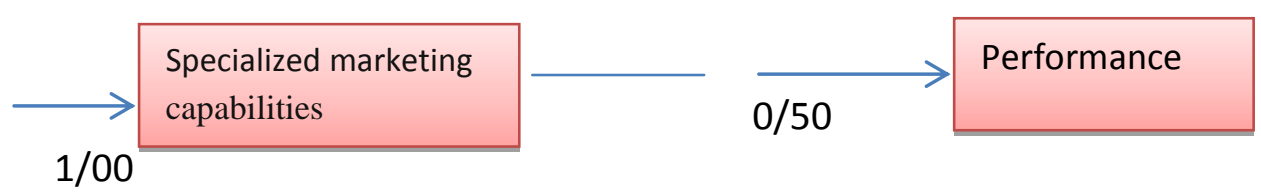

Table 3.index measurement model

\begin{tabular}{llllllll} 
Model & $\begin{array}{l}\text { chi- } \\
\text { square }\end{array}$ & $P$ & GFI & AGFI & RMSEA & CFI & NFI \\
\hline $\begin{array}{l}\text { Default } \\
\text { model }\end{array}$ & $152 / 54$ & $0 / 08$ & $0 / 86$ & $0 / 89$ & $0 / 08$ & $0 / 90$ & $0 / 89$ \\
\end{tabular}

Figure 3.t-test of the model 


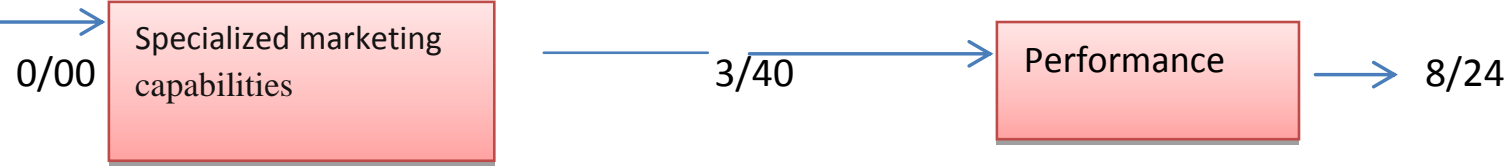

\begin{tabular}{|c|c|c|c|c|c|}
\hline Result test & & $\begin{array}{l}\mathrm{t}- \\
\text { value }\end{array}$ & $\begin{array}{l}\text { Path } \\
\text { coefficie } \\
\text { nt }\end{array}$ & Structural Effects & Structures \\
\hline $\begin{array}{l}\text { Reject the } \\
\text { hypothesis }\end{array}$ & null & $1 / 37$ & 0/09 & & Pricing \\
\hline $\begin{array}{l}\text { Reject the } \\
\text { hypothesis }\end{array}$ & null & $4 / 44$ & $0 / 28$ & & $\begin{array}{l}\text { Product } \\
\text { management }\end{array}$ \\
\hline $\begin{array}{l}\text { Reject the } \\
\text { hypothesis }\end{array}$ & null & $2 / 04$ & $0 / 28$ & & $\begin{array}{l}\text { Distributor } \\
\text { management }\end{array}$ \\
\hline $\begin{array}{l}\text { Reject the } \\
\text { hypothesis }\end{array}$ & null & $1 / 675$ & $0 / 51$ & & $\begin{array}{l}\text { Delivery } \\
\text { management }\end{array}$ \\
\hline $\begin{array}{l}\text { Reject the } \\
\text { hypothesis }\end{array}$ & null & $2 / 51$ & $0 / 11$ & & Post-sale service \\
\hline $\begin{array}{l}\text { Reject the } \\
\text { hypothesis }\end{array}$ & null & $1 / 76$ & $0 / 44$ & $\begin{array}{l}\text { Specialized } \\
\text { marketing } \\
\text { capabilities }\end{array}$ & $\begin{array}{l}\text { Marketing } \\
\text { communications }\end{array}$ \\
\hline $\begin{array}{l}\text { Reject the } \\
\text { hypothesis }\end{array}$ & null & $1 / 08$ & $0 / 62$ & $\begin{array}{l}\text { performance } \\
\text { marketing }\end{array}$ & Selling \\
\hline
\end{tabular}

\section{Conclusion}

specialized marketing capabilities is seen appropriate for Past industry. Besides, marketing capabilities can be seen as a crucial tool to gain competitive advantage for firms. Thus the survey examines the relationship between specialized marketing capabilities and performance marketing . Data collected through structured questionnaires administered face-to-face to marketing unit employees of 9 in the Past industry in Tehran. Analyses results that specialized marketing capabilities are positively related with marketing performance. It can be thus argued that the Past industry in Tehran do attach a great importance to consumers to reach higher performance. Besides, they tend to be proactive and emphasize the importance of marketing capabilities. Also they are aware of resource leveraging as a tool to compensate for resource scarcity they suffer in reaching high performance. The survey also revealed that Past industry in Tehran are taking as a way of reaching high performance. However, this survey is conducted on Past industry in Tehran findings might not be transferable to all types of organizations. Thus, it is recommended that further researches can be conducted on large-scale organizations and, also in different countries for the generalizability of findings. Also further surveys can be designed to explore relationship between specialized marketing capabilities and other performance indicators such as financial performance, customer performance. 


\section{IMPLICATIONS}

we developed a conceptual model, in which we embed specialized marketing capabilities and show their relationship to marketing performance unit. We distinguish between the long-term sustainable and the short-term efficiency role of specialized marketing capabilities.Our analysis supports all seven hypotheses and hence confirms both roles of specialized marketing capabilities. First, specialized marketing capabilities can have a sustainable yet indirect impact on firm performance if firms use specialized marketing capabilities to increase their stocks of marketing capabilities have positive effects on which, on positively affects firm performance. Taken together, these results support the notion that specialized marketing capabilities are indirect yet sustainable drivers of marketing performance. Second, if firms use specialized marketing capabilitie as efficiencyenhancers of marketing performance, specialized marketing capabilities also lead to short-term wins. However, statistical results show that moderate investments in specialized marketing capabilities have the highest efficiency-effect. The present study specifies and empirically tests the importance of specialized marketing capabilitiesin marketing performance context Future research could expand our work by integrating customers and suppliers perspectives on the specialized marketing capabilities of the supplier., future research could complement our findings by studying the extent to which resources and capabilities at the firm level influence capabilities at the firm venture level

\section{References}

1-Bonoma, T. V. (1985). The marketing edge: Making strategies work.

New York: Free Press

2-Day, G. S. (1994). The capabilities of market-driven companies. Journal of Marketing, 58(4), 37-51.

3-Jalali Seyyed Mehdi (2013) " Investigation of the Effective Factors on Brand Loyalty and Repurchase Intention " Research Journal of Recent Sciences Vol. 2(2), 10-17

4-Mohammad Reza Dalvi Esfahan, (2013) "The Effect of Internal Marketing on Outcomes and Factors Organizational Commitment " J. Basic. Appl. Sci. Res., 3(1)429-435, 2013

5-Hamid Tohidi*, Mohammad Mehdi Jabbari (2012) " Studying impact of organizational learning on innovating "Procedia - Social and Behavioral Sciences 31 (2012) 408 - 413

6-Neil A. Morgan \& Constantine S. Katsikeas \& Douglas W. Vorhies (2011)" Export marketing strategy implementation, export marketing capabilities, and export venture performance "

7-Grant, R. M. (1996). Prospering in dynamically-competitive environments: Organizational capability as knowledge integration. Organization Science, 7(4), 375-387.

8- Gungor Hacioglu "The effect entrepreneurial marketing on firms in novative performance inTurkis SEMS " Procedia - Social and Behavioral Sciences 58 ( 2012 ) 871 - 878 
9-Teece, D. J., Pisano, G., \& Shuen, A. (1997). Dynamic capabilities and strategic management. Strategic Management Journal, 18(7), 509-535.

10-Vorhies, D. W., \& Morgan, N. A. (2003). A configuration theory assessment of marketing organization fit with strategic type and its relationship with marketing performance. Journal of Marketing, 67

(1), 100-115.

11-Vorhies, D. W., \& Morgan, N. A. (2005). Benchmarking marketing capabilities for sustained competitive advantage. Journal of Marketing, 69(1), 80-94

12-Vorhies, D. W., Morgan, R. E., \& Autry, C. W. (2009). Product-market strategy and the marketing capabilities of the firm: Impact on market effectiveness and cash flow performance. Strategic Management Journal, 30(12), 1310-1334 